\title{
PENGARUH BUDAYA BAPAKISM DAN KEMATANGAN MANAJEMEN PORTOFOLIO TEKNOLOGI INFORMASI (MPTI) TERHADAP KINERJA PERUSAHAN
}

\author{
Ully Asfari, Apol Pribadi Subriadi \\ Jurusan Sistem Informasi, Fakultas Teknologi Informasi, Institut Teknologi Sepuluh Nopember \\ Kampus ITS, Sukolilo, Surabaya 60111 \\ Telp : (031) 5939214, Fax : (031) 5913804 \\ E-mail : ully.asfari@gmail.com
}

\begin{abstract}
This research aims to investigate the impact of local culture on firm performance in Indonesia. Bapakism pattern is a local culture which has become a character of Indonesian people. The bapakism is applied in not only happens family culture, but also in majority firms. This paper presents the nature of profit company. Bapakism would have been the first interest theory research to learn, because this culture has been felt by all employees of the company since Indonesia's historical relics. This research is that bapakism can be considered as a factor which has impact on the firm performance. Data was collected using questionnaires method and would be processed using SEM-GSCA software. These research finding suggest that bapakism has an impact on profit based company to get rationality of decision before investing TI. From the final result we higlight that bapakism culture must be considered to increase employee productivity and reach the firm goals.
\end{abstract}

\section{Abstrak}

Penelitian ini membahas pengaruh budaya lokal terhadap kinerja perusahaan di Indonesia. Patern bapakism merupakan budaya lokal yang menjadi karakter kehidupan masyarakat Indonesia. Bapakism tidak hanya berlaku di lingkungan keluarga, tapi juga diberlakukan di kebanyakan perusahaan. Paper ini melakukan percobaan secara natural di perusahaan profit. Bapakism akan menjadi penelitian teoritis pertama yang menarik untuk dikaji, karena budaya tersebut telah dirasakan seluruh karyawan perusahaan sejak peninggalan sejarah Indonesia. Melalui penelitian ini diharapkan, bapakism dipertimbangkan sebagai faktor yang berpengaruh pada kinerja perusahaan. Pengumpulan data menggunakan metode kuisioner yang kemudian diolah menggunakan perangkat lunak SEM - GSCA. Temuan yang didapat adalah budaya bapakism mempunyai pengaruh pada perusahaan profit pada proses pengambilan keputusan secara rasionalitas dalam melakukan investasi TI. Sehingga budaya bapakism perlu dipertimbangkan perusahaan untuk meningkatkan produktifitas karyawan dalam mencapai target perusahaan.

Kata kunci: kematangan manajemen portofolio TI, rasionalitas pengambilan keputusan, perilaku politik, bapakism, kinerja perusahaan, GSCA

\section{PENDAHULUAN}

Perusahaan mempunyai tanggung jawab untuk berkembang dan bertahan di kondisi pasar yang penuh ketidakpastian dalam jangka waktu yang lama. Salah satu cara perusahaan untuk bertahan yaitu dengan menginvestasikan sebagian keuangannya. Tidak sedikit perusahaan yang menginvestasikan keuangannya pada bidang TI (Teknologi Informasi) sebagai sarana memperlancar kegiatan internal dan eksternal perusahaan dalam mencapai tujuan bisnis yang disepakati. Banyak perusahaan yang berhasil menerapkan cara ini, namun tidak sedikit perusahaan yang mengalami kerugian karena investasi di bidang TI. Karena tidak menutup kemungkinan jika anggaran yang dikeluarkan semakin besar dari pengeluaran perusahaan sebelumnya.
Sebagian besar prosentase pengeluaran suatu perusahaan digunakan untuk investasi di bidang TI. Menurut Maizlish dan Handler (2005) pengeluaran tersebut mencapai $70 \%$ dari pengeluaran perusahaan. Untuk mencapai hasil yang maksimal dan sesuai dengan strategi bisnis perusahaan diperlukan suatu metode yang berguna untuk mengelola investasi TI. Menurut penelitian Maizlish dan Handler (2005) perusahaan yang menggunakan Portofolio Teknologi Informasi mendapat nilai yang signifikan dari investasi yang telah dilakukan.

McFarlan (1981) dikenal sebagai peneliti pertama yang mengusulkan pendekatan portofolio untuk mengelola proyek TI. Investasi TI ditiap perusahaan mengalami perkembangan dari waktu ke waktu, hal ini dipengaruhi oleh faktor eksternal dan internal perusahaan. Saat investasi TI semakin berkembang menjadi aset strategis perusahaan, mengakibatkan 
adanya evolusi dari manajemen portofolio TI untuk semakin luas (Verhoef, 2002).

Terdapat juga hal-hal yang terkait antara kematangan perusahaan dan kinerja perusahaan. Hal tersebut adalah rasionalitas dalam pengambilan keputusan dan perilaku politik internal perusahaan, dua proses ini menjadi bagian dari tolok ukur kinerja perusahaan.

Rasionalitas pengambilan keputusan merupakan suatu tindakan yang diambil para pemegang peran penting perusahaan untuk perkembangan perusahaan. Proses pengambilan keputusan ini membutuhkan banyak informasi yang mendukung dan dianjurkan diperoleh dari berbagai sisi. Sehingga diharapkan keputusan yang diambil dapat dipertanggunjawabkan dalam kurun waktu yang ditentukan.

Perilaku politik yaitu tindakan dari sebuah individu atau kelompok yang didalamnya terdapat unsur politik. Hal ini biasanya terkait dengan kecurangan atau tindakan diluar peraturan yang telah ditentukan organisasi.

Salah satu faktor yang melekat pada masing-masing individu adalah faktor budaya. Faktor budaya merupakan faktor eksternal yang tidak dapat ditentang, sehingga perusahaan perlu beradaptasi dengan faktor lingkungan yang dominan ini. Unsur budaya lokal di Indonesia dan beberapa negara di Asia seperti Thailand dan Malaysia mempunyai paham atau patern bapakism. Patern bapakism menjadi ciri khas masyarakat di aspek politik, sosial dan ekonomi. Patern ini merupakan paham yang melambangkan sebuah ketua yang harus dipatuhi dan dilindungi oleh bawahannya.

Indonesia mempunyai budaya yang beraneka ragam. Pribahasa yang menggambarkan kondisi Indonesia hingga saat ini "dimana bumi dipijak, disitulah langit dijunjung" merupakan perumpamaan yang menjelaskan bahwa kebijakan atau peraturan atau budaya yang berlaku disuatu lokasi, sebaiknya dipatuhi dan dijalankan. Dengan adanya budaya disuatu daerah mau tidak mau akan berpengaruh atas kesinergisan antara rasionalitas pengambilan keputusan dan perilaku politik masyarakat sekitar.

\section{KAJIAN TEORI}

Kajian teori yang digunakan dalam penelitian ini diperoleh dari kajian penelitian sebelumnya. Terdapat lima teori dasar yang digunakan, antara lain kematangan MPTI, rasionalitas pengambilan keputusan, perilaku politik, bapakism dan kinerja perusahaan.

\subsection{Kematangan MPTI}

Manajemen portfolio TI merupakan kombinasi dari berbagai tool dan metode yang digunakan untuk mengukur, mengontrol, dan meningkatkann return dari investasi TI dan pengeluaran perusahaan pada umumnya untuk memenuhi tujuan-tujuan bisnis tanpa melebihi sumber daya yang telah tersedia atau melebihi batas lain (Maizlish \& Handler, 2005).

TI pada perusahaan diharapkan mampu mendukung tercapainya tujuan bisnis perusahaan. Manajemen puncak perlu memantau bagaimana cara TI dalam mendukung keputusan, hasil dari return of investment (ROI) dan pengelolaan secara teknis dari TI tersebut. Agar manajemen puncak dapat memperoleh transparansi dalam membuat keputusan TI, dan membuat pengeluaran yang tepat. TI juga diharapkan mampu mengelola faktor-faktor yang menjadi resiko dalam suatu proyek. Akhirnya, jika TI mempunyai kontribusi yang besar bagi organisasi, karyawan perlu memikirkan cara untuk mengurangi biaya operasionalnya dan memindahkan simpanan ke bisnis atau investasi pada proyek strategis yang baru.

Menurut Jeffery \& Leliveld (2004) dan Reyck et al. (2005) pengukuran kematangan MPTI dapat dilakukan dengan menggunakan sembilan indicator yaitu sentralisasi/pemusatan, metrik finansial, teknik pengambilan keputusan, analisis resiko, saling ketergantungan, batasan-batasan, keterlibatan manajemen puncak, optimasi, dan software khusus.

\subsection{Rasionalitas Pengambilan Keputusan}

Dalam mengelola suatu ide dan proyek selalu melewati proses pengambilan keputusan yang diambil secara fleksibel dimana pendekatan yang berbeda diperbolehkan untuk digunakan. Namun dari pendekatan tersebut disaring lagi oleh MPTI sehingga pengambil keputusan bisa mengetahui apakah pendekatan tersebut dapat digunakan atau tidak (Gutiérrez \& Magnusson, 2014). Untuk melakukan pengambilan keputusan final perusahaan diperlukan adanya pertimbangan yang matang yang mampu menanggulangi tingkat ketidakpastian yang tinggi.

Menurut Hitt \& Tyler (1991) rasionalitas pengambilan keputusan seperti "rangkaian proses analitis dimana sebuah kumpulan kriteria objektif digunakan untuk alternatif evaluasi”. Dimensi ini menekankan tinggat kritis dari kelengkapan dan keterkaitan informasi.

Hasil dari kajian penelitian Dean \& Sharfman (1993, 1996), Goll \& Rasheed (2005) mengenai pengukuran rasionalitas pengambilan keputusan ditemukan tujuh indikator, antara lain: penggunaan analisis, pencarian informasi, analisis - intuisi, metode kuantitatif, tingkat fokus pada informasi, 
sosialisasi perubahan dan komunikasi.

\subsection{Perilaku Politik}

Salah satu faktor penting yang mempengaruhi kesuksesan proses implementasi sistem informasi adalah perilaku politik. Kekuatan perilaku politik ini dibawa oleh individu-individu dari suatu organisasi, mereka menggunakan emosinya (frustrasi, rasa tidak percaya, loyalitas) dalam mempengaruhi politik (Eisenhardt \& Bourgeois, 1988). Faktor ini harus dijaga agar tidak mempengaruhi tujuan awal organisasi. Mengutip dari Allen et al. (1979) dan (Dean \& Sharfman, 1996), tindakan kesengajaan dalam mempengaruhi keputusan untuk meningkatkan atau melindungi kepentingan individu atau kelompok. Biasanya terdiri dari koalisi orang-orang yang mungkin bertentangan tujuan atau bersaing kepentingan (Eisenhardt \& Bourgeois, 1989).

Menurut Dean dan Sharfman (1996) perilaku politik dapat diukur melalui empat indikator yaitu individu - organisasi, terbuka pada preferensi, penggunaan negosiasi, dan penggunaan kekuatan.

\subsection{Bapakism}

Budaya adalah sebuah konsep dunia yang telah didiskusikan selama ribuan tahun oleh antropologi, sosiologi, sejarah dan filosofi. budaya ada satu rangkaian dari nilai, kepercayaan, pemahaman umum, pemikiran dan norma dari sebuah kebiasaan itu yang dijelaskan oleh beberapa orang (William, 2007). Budaya merupakan istilah yang terkenal susah didefinisikan (Smith, 2001). Beberapa orang tidak bisa mendefinisikannya tapi bisa merasakannya. Budaya menyediakan tuntunan pada kebiasaan pada sebuah lingkungan, sehingga mampu mempengaruhi seseorang dalam mengambil keputusan (William, 2007).

Di Indonesia pola budaya yang dikenal dengan nama bapakism tetap berjalan hingga saat ini. Patern ini dikenal sejak jaman Presiden Soeharto menjabat sebagai presiden Indonesia pada masa Era Baru sekitar tahun 1996-1998. Bapakism menjadi budaya turun-temurun yang dibawa dari nenek moyang penduduk Indonesia. Bapakism adalah suatu budaya yang menggambarkan sistem yang kompleks dari suatu kelompok yang relatif sangat pribadi dan saling timbal balik antar sesama, budaya ini mayoritas merupakan kehidupan masyarakat Jawa (Jackson, 1978).

Salah satu masalah utama mengidentifikasi adalah bahwa ada tingkat sentralisasi kekuasaan, dengan otoritas yang ditelusuri kepada satu individu. Hal ini tidak mengejutkan karena penelitian sebelumnya (Rademakers, 1998; Geertz, 1972) telah mengidentifikasi sentralisasi otoritas sebagai karakteristik kunci dari masyarakat Jawa.
Paternalisme ini atau 'bapakism' dari masyarakat Jawa, yang berbentuk kontrol manajemen dalam organisasi. Hal ini dirasakan oleh sebagian besar karyawan sebagai figur ayah, membuat semua keputusan penting dan semua karyawan harus mematuhi keputusan tersebut: bapak (Mulder, 1989).

Hasil kajian dari penelitian sebelumnya, ditemukan enam indikator pengukur budaya bapakism, antara lain: pemimpin (bapak), sentralisasi, asal bapak senang (ABS), loyalitas, rukun, dan perayaan.

\subsection{Kinerja Perusahaan}

Kinerja perusahaan merupakan suatu indikator untuk mengetahui kemampuan inti dari perusahaan. Menurut Kamus Besar Bahasa Indonesia, kinerja merupakan kemampuan kerja dari apa yang ingin dicapai. Dapat diartikan bahwa proses pencapaian suatu target perusahaan dalam jangka waktu tertentu (Subriadi, 2013). Pencapaian kinerja yang baik jika memenuhi dan mencapai target perusahaan (Ho, 2008). Sebagian besar pembahasan terkait kinerja perusahaan didominasi dengan dampak dari keuangan perusahaan dan bagaimana cara perusahaan dalam bertahan dan memenuhi permintaan pasar.

Pengukuran kinerja perusahaan dilakukan dengan dua indikator pendukung yakni market share dan operasional organisasi.

\section{METODOLOGI}

Survei penelitian ini dilakukan dengan metode kuisoner yang ditujukan langsung kepada salah satu perusahaan telekomunikasi sebagai perusahaan yang mewakili perusahaan profit di Jawa Timur.

Penelitian dikerjakan melalui beberapa tahapan yakni pengembangan model, penyusunan instrumen penelitian, uji instrumen penelitian, survei dan analisis hasil hingga mengahsilkan hasil analisis.

Pengembangan model dari penelitian ini terdapat hipotesis yang menjadi faktor pendukung pengujian hasil. Proses pengujian dan analisis model berupa penelitian kausalitas, deskriptif dan kuantitatif. Pada penyusunan instrumen dibuat beberapa pernyataan yang mewakili variabel berserta indikator pendukung dalam model konseptual penelitian.

Analisis deskriptif dilakukan juga dengan mendeskripsikan data berdasarkan kecenderungan dari tanggapan responden terhadap item pertanyaan. Karakteristik responden juga dapat diketahui melalui analisis pernyataan yang berkaitan variabel penelitian dan indikator pendukung di dalamnya. 
Asfari, dkk., Pengaruh Budaya Bapakism dan Kematangan Manajemen Portofolio..

Langkah terakhir yaitu dilakukan analisis inferensial untuk menganalisis data dengan menggunakan pendekatan variance based atau component based dengan alat bantu Generalized Structured Component Analysis (GSCA). Sebelum menjalankan tahap ini, perlu dilakukan proses pengujian reliabilitas, validitasn, dan linieritas terkait data yang terkumpul. GSCA dipilih karena sangat cocok untuk pengujian model berbasis teori yang didalamnya terdapat hubungan antar variabel pada model struktural.

\subsection{Menentukan Model}

Sub bab ini bertujuan untuk menjelaskan kostruk model yang digunakan sebagai acuan penelitian.

\section{Pembuatan Model Konseptual}

Dalam upaya menghindari tingginya tingkat ambiguitas, MPTI merupakan sebuah tool yang mampu mengatasi kekhawatiran organisasi dalam berinvestasi. Dolci dan Maçada (2011) mengatakan dalam penelitiannya bahwa MPTI mampu membantu manajer dalam memahami dengan baik dan menata investasi TI, hal ini sangat penting untuk mempermudah manajemen.

Terutama dalam hal pengambilan keputusan. Pada literatur pengambilan keputusan ditemukan beberapa strategi terkait proses pengambilan keputusan yaitu rasionalitas \& comprehensiveness, dan perilaku politik (Dean \& Sharfman, 1993). Dari strategi tersebut terdapat dua dimensi utama yang mendukung penelitian ini, yaitu rasionalitas pengambilan keputusan dan perilaku politik. Menurut analisis yang dilakukan Miller \& Cardinal (1994) dan Schwenk \& Shrader (1993) terdapat hubungan positif dan signifikan terhadap perencanaan dan kinerja.

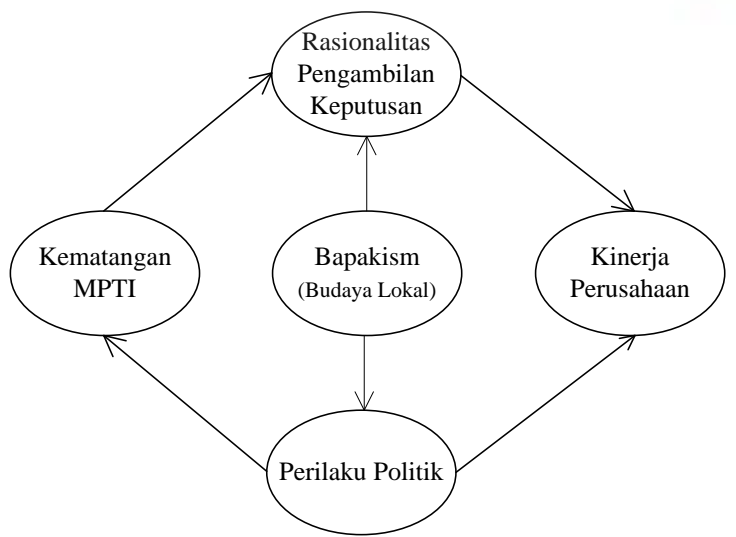

Gambar 1. Kontruk Model Peneliti (Sumber: Peneliti, 2014)

Faktor budaya mempunyai pengaruh besar terhadap individu-individu yang bertugas sebagai pengambil keputusan. Budaya juga sangat kental dengan perilaku politik yang dipelihara di suatu lingkungan organisasi. Menurut Scholz (1987), adanya suatu klaim yang menyatakan bahwa budaya organisasi berkaitan/berpengaruh dengan kinerja perusahaan. Sehingga hasil konstruk model yang digambarkan dapat dilihat pada Gambar 1.

Penentuan Indikator

Tiap variabel yang tersusun pada Gambar 1 memiliki beberapa indikator. Indikator tersebut didapat dari studi litertaur yang telah dilakukan sebelumnya, rekap indikator dapat dilihat pada Tabel 1.

Tabel 1. Indikator Pada Variabel Penelitian

\begin{tabular}{|c|c|}
\hline Variabel laten & Indikator \\
\hline \multirow{11}{*}{$\begin{array}{l}\text { Kematangan } \\
\text { MPTI }\end{array}$} & Sentralisasi / Pemusatan \\
\hline & Metrik Finansial \\
\hline & Pengambilan \\
\hline & Keputusan \\
\hline & Analisis Resiko \\
\hline & Saling Ketergantungan \\
\hline & Batasan-Batasan \\
\hline & Keterlibatan \\
\hline & Puncak \\
\hline & Optimasi \\
\hline & Software Khusus \\
\hline \multirow{7}{*}{$\begin{array}{l}\text { Rasionalitas } \\
\text { Pengambilan } \\
\text { Keputusan }\end{array}$} & Penggunaan Analisis \\
\hline & Pencarian Informasi \\
\hline & Analisis - Intuisi \\
\hline & Metode Kuantitatif \\
\hline & Tingkat Fokus Pada Informasi \\
\hline & Sosialisasi Perubahan \\
\hline & Komunikasi \\
\hline \multirow{4}{*}{$\begin{array}{l}\text { Perilaku } \\
\text { Politik }\end{array}$} & Tujuan Individu - Organisasi \\
\hline & Terbuka Pada Preferensi \\
\hline & Melakukan Negosiasi \\
\hline & Penggunaan Kekuatan \\
\hline \multirow{6}{*}{$\begin{array}{l}\text { Budaya } \\
\text { (Bapakism) }\end{array}$} & Pemimpin (Bapak) \\
\hline & Sentralisasi \\
\hline & Asal Bapak Seneng (ABS) \\
\hline & Loyalitas \\
\hline & Rukun \\
\hline & Perayaan \\
\hline Kinerja & Market Share \\
\hline Perusahaan & Operasional Organisasi \\
\hline
\end{tabular}

\subsection{Pengumpulan Data}

Penelitian ini diarahkan pada perusahaan yang memiliki tingkat penggunaan TI dengan kompleksitas yang tinggi. Sampel diambil dari 70 karyawan dari PT. Telkom Indonesia.

Analisis Data

Hasil dari kuisioner yang telah disebar, terdapat 15 kuisioner yang tidak layak dan tidak kembali. Sehingga jumlah kuisioner yang layak untuk diolah sejumlah 40 kuisioner dari responden atau 57,14\% dari total populasi. Pengujian instrumen penelitian selanjutnya dilakukan dengan uji reliabilitas, uji validitas dan uji linieritas menggunakan perangkat lunak yang bernama SPSS for Windows versi 17 . 
Pada penelitian ini telah dinyatakan lolos uji reliabilitas, validitas dan linieritas. Data dapat dikatakan reliabel jika Reliabilitas pernyataan diketahui melalui Cronbach Alpha, dimana semakin dekat koefisien alpha dengan nilai 1 , berarti itemitem pernyataan dalam instrumen semakin reliabel (Ghozali, 2006). Untuk hasil uji validitas dari pernyataan tersebut dikatakan valid apabila bilangan koefisien korelasi antara nilai suatu indikator dengan total nilai seluruh indikator adalah $>0.3$ atau nilai signifikansi $(p$-value $)<0.05$ (Solimun, 2002).

Setelah melewati uji reliabilitas, validitas, dan linieritas data akan dianalisis menggunakan Generalized Structured Component Analysis (GSCA). Karena software ini mampu mengolah data yang bersifat reflektif dan formatif dalam waktu yang sama (Hwang and Takane, 2004).

Uji hipotesis yang dilakukan pada penelitian ini sebagai berikut:

1) H1: Kematangan MPTI mempengaruhi rasionalitas dalam membuat keputusan investasi TI

2) H2: Kematangan MPTI berpengaruh terhadap tingkat perilaku politik organisasi.

3) H3: Tingkat rasionalitas pengambilan keputusan mempengaruhi kinerja organisasi.

4) H4: Perilaku politik internal organisasi mempunyai dampak pada kinerja organisasi.

5) H5: Budaya (bapakism) pada organisasi mempunyai pengaruh terhadap rasionalitas dalam pengambilan keputusan dalam investasi TI.

6) H6: Pengaruh nilai budaya (bapakism) pada organisasi terhadap perilaku politik organisasi.

\section{Analisis Deskriptif}

Pada perusahaan profit nilai mean pada kinerja perusahaan mendapatkan nilai tertinggi yakni sebesar 3,453, sedangkan nilai mean terendah ada pada variabel kematangan MPTI aykni sebesar 3.132. Variabel kematangan MPTI memperoleh nilai mean yang rendah dikarenakan sistem pengukuran indikator dari nilai 1-4, hal itu juga mempengaruhi nilai mean yang dihasilkan perangkat lunak GSCA.

\section{Analisis Inferensial}

Perangkat lunak GSCA mampu mengolah data dengan dua sifat yaitu reflektif dan formatif. Pada konstruk penelitian terdapat empat variabel dengan sifat reflektif, yakni pada variabel kematangan MPTI, rasionalitas pengambilan keputusan, bapakism, dan kinerja perusahaan. Untuk variabel perilaku politik memiliki sifat formatif dalam pembuatan konstruk model.

Dalam analisis GSCA, pengukuran goodness of fit model dapat dilakukan dengan mengevaluasi nilai
FIT dan Adjusted FIT (AFIT). Hasil pada Tabel 5.40 terlihat nilai FIT pada perusahaan profit sebesar 0,860 yang artinya model mampu menjelaskan $86,0 \%$ variasi dari data yang ada. Dapat juga diartikan bahwa keragaman Kematangan MPTI, Rasionalitas Pengambilan Keputusan, Perilaku potik, dan Bapakism (Budaya Lokal) mampu mempengaruhi Kinerja Perusahaan sebesar 86,0\% dan signifikan pada tingkat $95 \%$. Sedangkan sisa nya sebesar $14,0 \%$ dapat dijelaskan oleh variabel lain yang tidak masuk dalam konstruk model penelitian ini.

Tabel 2. Hasil Measure of Fit Structural Model

\begin{tabular}{cc}
\hline \multicolumn{2}{c}{ Model Fit } \\
\hline FIT & 0.860 \\
AFIT & 0.853 \\
NPAR & 58 \\
\hline
\end{tabular}

Tabel 3. Rangkuman R square Variabel Laten

\begin{tabular}{cc}
\hline \multicolumn{2}{c}{ R square of Latent Variable } \\
\hline Kematangan MPTI & 0 \\
Rasionalitas Pengambilan Keputusan & 0.980 \\
Bapakism & 0 \\
Perilaku Politik & 0.954 \\
Kinerja Perusahaan & 0.948 \\
\hline
\end{tabular}

Pada perusahaan profit, variabel kematangan MPTI dan bapakism memberikan kontribusi yang mampu menjelaskan variabel rasionalitas pengambilan keputusan sebesar 98,0\%, sisanya 2,0\% dijelaskan oleh variabel lain. Variabel kematangan MPTI memberikan kontribusi yang mampu menjelaskan variabel perilaku politik sebesar 95,4\%, sisanya $4,6 \%$ dijelaskan oleh variabel lain. Variabel rasionalitas pengambilan keputusan dan perilaku politik memberikan kontribusi yang mampu menjelaskan variabel kinerja perusahaan sebesar $94,8 \%$, sisanya $5,2 \%$ dijelaskan oleh variabel lain.

\section{Pengujian Hipotesis}

Pengujian Hipotesis dalam penelitian ini dapat dianalisis dari nilai yang ditunjukkan oleh output GSCA yang berupa Path Coefficients pada measures of fit model struktural. Pada hasil tersebut terdapat nilai estimate, standard error, dan critical ratio yang dapat dikaji lebih lanjut, karena Path Coefficients menggambarkan hubungan setiap variabel.

Signifikansi dapat diketahui dari nilai critical ratio pada Tabel 2. Terdapat empat critical ratio dengan tanda bintang (*), hal ini menandakan bahwa kedua variabel tersbut saling mempengaruhi secara positif signifikan.

Tabel 4. Path Coefficients pada Perusahaan Profit

\begin{tabular}{|l|l|l|l|}
\hline \multicolumn{4}{|c|}{ Path Coefficients } \\
\hline & Estimate & SE & CR \\
\hline
\end{tabular}




\begin{tabular}{|c|c|c|c|}
\hline $\begin{array}{c}\text { Kematangan MPTI- } \\
\text { >Rasionalitas Pengambilan } \\
\text { Keputusan }\end{array}$ & 0.608 & 0.074 & $8.22^{*}$ \\
\hline $\begin{array}{c}\text { Kematangan MPTI- } \\
\text { >Perilaku Politik }\end{array}$ & 0.596 & 0.140 & $4.25^{*}$ \\
\hline $\begin{array}{c}\text { Rasionalitas Pengambilan } \\
\text { Keputusan->Kinerja } \\
\text { Perusahaan }\end{array}$ & 0.829 & 0.206 & $4.03^{*}$ \\
\hline $\begin{array}{c}\text { Bapakism->Rasionalitas } \\
\text { Pengambilan Keputusan }\end{array}$ & 0.393 & 0.074 & $5.28^{*}$ \\
\hline Bapakism->Perilaku Politik & 0.392 & 0.143 & $2.73^{*}$ \\
\hline $\begin{array}{c}\text { Perilaku Politik->Kinerja } \\
\text { Perusahaan }\end{array}$ & 0.148 & 0.207 & 0.72 \\
\hline CR* = significant at 05 level & & & \\
\hline
\end{tabular}

Hasil hipotesis yang didapat dari output GSCA tersebut adalah:

Tabel 5. Hasil Hipotesis

\begin{tabular}{cc}
\hline Hipotesis & Hasil \\
\hline H1 & Diterima \\
H2 & Ditolak \\
H4 & Diterima \\
H5 & Ditolak \\
H6 & Diterima \\
\hline
\end{tabular}

\section{DISKUSI}

Hasil dari penelitian dapat disimpulkan bahwa model dapat diterima berdasarkan pengujian data dengan menggunakan perangkat lunak SEM-GSCA dalam perhitungan pengaruh kematangan MPTI terhadap rasionalitas karyawan dalam pengambilan keputusan dan perilaku politik, kemudian pengaruh dari bapakism (budaya lokal) terhadap rasionalitas pengambilan keputusan dan perilaku politi yang akhirnya berdampak pada kinerja perusahaan.

\section{Kontribusi Teoritis}

Penelitian ini menegaskan teori Kaplan (2005) bahwa dengan matangnya MPTI di suatu perusahaan mampu mengurangi politik dalam pembuatan keputusan, yang akhirnya dapat meningkatkan kualitas keputusan. Penelitian ini merespon penelitian Oh, Loong-Tatt $\mathrm{Ng}$, \& Teo (2007) terkait pengukuran kematangan TI dilakukan dengan mencermati masing-masing faktor yang mempengaruhi perusahaan dalam mengambil keputusan yang rasional. Hasil dari penelitian ini masih memunculkan spekulasi dari pernyataaan tersebut, bahwa pada pengaruh kematangan MPTI terhadap rasionalitas kematangan MPTI tidak berlaku di segala macam perusahaan. Kondisi ini dibuktikan pada salah satu kategori perusahaan dimana kematangan MPTI mempunya korelasi yang tidak signifikan terhadap rasionalitasn pengambilan keputusan.

Hasil penelitian terkait pengukuran kinerja perusahaan pada perusahaan profit mampu membuktikan analisis Miller \& Cardinal (1994) dan Schwenk \& Shrader (1993) bahwa rata-rata hubungan antara perencanaan formal dan kinerja berhubungan positif dan signifikan.

Pada penelitian Dean \& Sharfman (1996) mengindikasikan bahwa variabel rasionalitas pengambilan keputusan dan perilaku politik merupakan dua variabel paralel yang berbeda. Kedua variabel ini berjalan sejajar dalam lingkungan perusahaan, karena merupakan variabel yang berbeda dalam. Namun pada penelitian ini konsep tersebut mampu membuktikan bahwa budaya lokal (bapakism) mampu mempengaruhi rasionalitas pengambilan keputusan dan perilaku politik yang dilakukan di perusahaan profit. Budaya bapakism dapat diukur menggunakan enam faktor yang telah disetarakan dengan grand teori mengenai budaya organisasi milik Hofstede (1991) dan Quinn \& Cameron (1983).

Kontribusi Praktis

Penelitian ini mempunyai kontribusi praktis bagi perusahaan profit, berikut kontribusi praktis yang diperoleh:

Patern bapakism mempunyai pengaruh yang signifikan di perusahaan, bapakism merupakan budaya yang tidak perlu dihilangkan atau malah sulit untuk dihilangkan, karena karyawan tumbuh bersama budaya tersebut. Bapakism di suatu perusahaan dapat dikelola manajemen puncak agar selaras dengan tujuan bisnis perusahaan. Kondisi ini sangat perlu dipadu-padankan dengan sifat profesional yang ditanamkan perusahaan kepada internal perusahaan, agar investasi TI yang diputuskan tidak berlandaskan perilaku politik dari karyawan.

Nilai variabel yang masih kurang yaitu variabel perilaku politik. Pada bahasan perilaku politik terdapat empat indikator pengukur yang digunakan yaitu tujuan individu - organisasi, terbuka pada preferensi, melakukan negosiasi dan penggunaan kekuatan.

Menurut hasil wawancara terhadap manajemen puncak menyadari adanya perilaku politik di perusahaan. Nara sumber tidak mengelak kondisi tersebut, namun besar kecilnya aktivitas politik tersebut sangat kecil. Kondisi perilaku politik tidak sama antar perusahaan satu dengan yang lainnya. Hal ini dipengaruhi juga prosedural yang berlaku di perusahaan. Salah satu cara untuk mengurangi tingginya perilaku politik di perusahaan politik dengan meningkatkan kematangan MPTI di perusahaan, tidak hanya pada manajemen puncak namun hingga tingkat teknisi juga mengimplementasikan prosedur perusahaan. 
Penilaian perilaku politik di perusahaan merupakan hal yang sensitif untuk diangkat dalam suatu kajian. Salah satu cara untuk memperkuat suatu data terkait nilai perilaku politik di perusahaan dilakukan dengan cara penelitian kualitatif. Hal tersebut mampu menambah keakuratan data dalam penelitian.

\section{KESIMPULAN DAN SARAN}

Berdasarkan uraian dari hasil analisis dan pembahasan pada bab sebelumnya, maka diperoleh kesimpulan sebagai berikut:

1. Kematangan MPTI di perusahaan profit dalam penelitian ini terbukti memberikan pengaruh terhadap rasionalitas pengambilan keputusan investasi TI. Manfaat tersebut mampu meningkatkan tingkat rasionalitas manajemen puncak dalam mengambil keputusan.

2. Rasionalitas pengambilan keputusan untuk melakukan investasi TI yang ada pada perusahaan profit berpengaruh terhadap pencapaian kinerja perusahaan. Penggunaan analisis dan dilakukannya metode kuantitatif merupakan faktor dominan dalam pembuatan keputusan. Keputusan yang rasional memberikan kontribusi yang signifikan pada kinerja market share dan operasional perusahaan.

3. Bapakism (budaya lokal) terbukti berpengaruh pada variabel rasionalitas pengambilan keputusan. Sifat pemimpin (kebapakan) dari manajemen puncak yang didukung loyaitas karyawan terhadap manajemen puncak, mempercepat terkumpulnya analisis informasi relevan yang berguna dalam pembuatan keputusan yang cepat dan berkualitas sebelum melakukan investasi TI.

4. Hubungan bapakism (budaya lokal) terhadap variabel perilaku politik pada perusahaan profit memiliki pengaruh yang positif signifikan. Tingginya loyalitas dan kebiasaan rukun mampu memunculkan indikasi munculnya perilaku politik. Budaya pada suatu lokasi dipengaruhi oleh peran dan sikap manajemen puncak dalam kesehariannya, jika pihak manajemen mencontohkan perilaku politik di perusahaan maka karyawan juga melakukan hal yang sama atau sebaliknya.

5. Perilaku politik tidak berpengaruh pada kinerja perusahaan. Indikasi terhadai tujuan individu, terbuka pada preferensi, penggunaan negosiasi, dan penggunaan kekuatan terkait perilaku politik perlu diwaspadai manajemen puncak. Karena di masing-masing perusahaan memiliki perilaku politik yang berbeda yang berdampak negatif terhadap kinerja perusahaan.

6. Bapakism mempunyai pengaruh yang signifikan terhadap kinerja perusahaan, budaya lokal ini cukup kental di masing-masing perusahaan sehingga kondisi tersebut mempengaruhi cara berpikir dari masing-masing karyawan dalam mengambil keputusan terkait investasi TI.

Beberapa saran yang dapat diberikan terkait dengan hasil penelitian ini yaitu penelitian terkait kematangan MPTI sebaiknya melibatkan banyak perusahaan dari berbagai bidang, seperti jasa/layanan, otomotif dan lain-lain. Sehingga terdapat penggolongan data berdasarkan bidang perusahaan. Hasil penelitian tersebut diharapkan dapat mengangkat budaya bapakism dari berbagai perspektif tipe perusahaan.

\section{DAFTAR RUJUKAN}

Allen, R. W., Madison, D. L., Renwick, P. A., \& Mayes, B. T. (1979). Organisational Politics : Tactics and Characteristics of Its Actors. California Management Review, 22(1). 77-83.

Bourgeois, L. J. (1985). Strategic goals, perceived uncertainty, and economic performance in volatile environments. Academy of Management Journal, 28, 548-573.

Bourgeois, L. J., \& Eisenhardt, K. M. (1988). Strategic decision processes in high velocity environments: Four cases in the microcomputer industry. . Management Science 34, 816-835.

Cooper, R. G., Edgett, S. J., \& Kleinschmidt, E. J. (2000). New problems, new solutions: Making portfolio management more effective. Research Technology Management, 43(2), 18-33.

Cooper, R. G., Edgett, S., \& Kleinschmidt, E. (1998). Portfolio Management for New Products. Perseus Books, Reading, USA.

Datz, T. (2003). How to do IT right. CIO, 16 (14).

Dawidson, O. (2006). Project portfolio management - an organizing perspective. (Ph.D. dissertation), Chalmers University of Technology, Sweden.

Dean, J. W., \& Sharfman, M. P. (1993). The Relationship between Procedural Rationality and Political Behavior in Strategic Decision Making.

Dean, J. W., \& Sharfman, M. P. (1996). Does decision process matter A study of strategicdecision-making effectiveness.

Diamantopoulos, A., \& Winklhofer, H. M. (2001). Index construction with formative indicators: An alternative to scale development. Journal of Marketing Research, 38(2), 269-277.

Dolci, P. C., \& Maçada, A. C. (2011). The Dimensions Of It Portfolio Management (Itpm): An Analysis Involving It Managers In Brazilian Companies .

Eisenhardt, K. M., \& Bourgeois, L. J. (1989). Charting strategic decisions in the microcomputer industry: Profile of an industry star. In Managing complexity in high technology organisations, systems and people (Glinow, M. V. and Mohrmann, S., Eds). 74- 89. 
Asfari, dkk., Pengaruh Budaya Bapakism dan Kematangan Manajemen Portofolio..

Eisenhardt, K. M., \& Zbaracki, M. (1992). Strategic Decision Making. Strategic Management Journal, 13, 17-37.

Eisenhardt, K., \& Bourgeois, L. (1988). Politics of Strategic Decision Making in High Velocity Environments: Toward a Midrange Theory. The Academy of Management Journal 31(4), 737770.

Elbanna, S., \& Child, J. (2007). Influences on strategic decision effectiveness: Development and test of an integrative model. Strategic Management Journal 28(4), 431-453.

Geertz, C. (1972). The politics of meaning' in culture and politics in Indonesia. 319-335.

Goll, I., \& Rasheed, A. A. (2005). The relationships between top management demographic characteristics, rational decision making, environmental munificence, and firm performance. Organisation Studies, 26(7), 9991023.

Gutiérrez, E., \& Magnusson, M. (2014). Dealing with legitimacy A key challenge for Project Portfolio Management decision makers. International Journal of Project Management 32, 30-39.

Hitt, M. A., \& Tyler, B. B. (1991). Strategic decision models: Integrating different perspectives. Strategic Management Journal, 12(5), 327-351.

Hofstede, G. (1991). Culture and organizations: Software of the mind.

Hofstede, G. (2001). Culture's consequences 2nd edition.

Jackson, K. D. (1978). The political implications of structure and culture in Indonesia. In Political Power and Communications in Indonesia,Karl Jackson and Lucian.

Jeffery, M., \& Leliveld, I. (2004). Best Practice in IT Portfolio Management.

Kamus bisnis online (http://www.businessdictionary.com/definition/r ational-decision-making.html). (t.thn.).

Maizlish, B., \& Handler, R. (2005). IT Portfolio Management Step-by-Step.

Miller, C. C., \& Cardinal, L. B. (1994). Strategic planning and firm performance: A synthesis of two decades of research Academy of Management Journal. 1649-1665.

Mulder, N. (1989). Individual and Society in Java: A Cultural Analysis, Gadjah Mada .

Oh, L. B., Loong-Tatt Ng, B., \& Teo, H. H. (2007). IT Portfolio Management: A Framework For Making Strategic IT Investment Decisions.

Rademakers, M. F. (1998). Market organization in Indonesia: Javanese and Chinese family business in the Jamu industry. Organization Studies, 120.

Reyck, B. D., Grushka-Cockayne, Y., Lockett, M., Calderini, S. R., Moura, M., \& Sloper, A. (2005). The impact of project portfolio management on information technology projects. International
Journal of Project Management, 23(7), 524-537.

Schwenk, C. R., \& Shrader, C. B. (1993). Effects of formal strategic planning on financial performance in small firms: A meta-analysis Entrepreneurship: Theory and Practice, 17(3). 53-64.

Smith, P. (2001). Cultural Theory: An Introduction. Oxford: Blackwell Publishing.

Verhoef, C. (2002). Quantitative IT Portfolio Management. Science of Computer Programming, 45(1), 1-96.
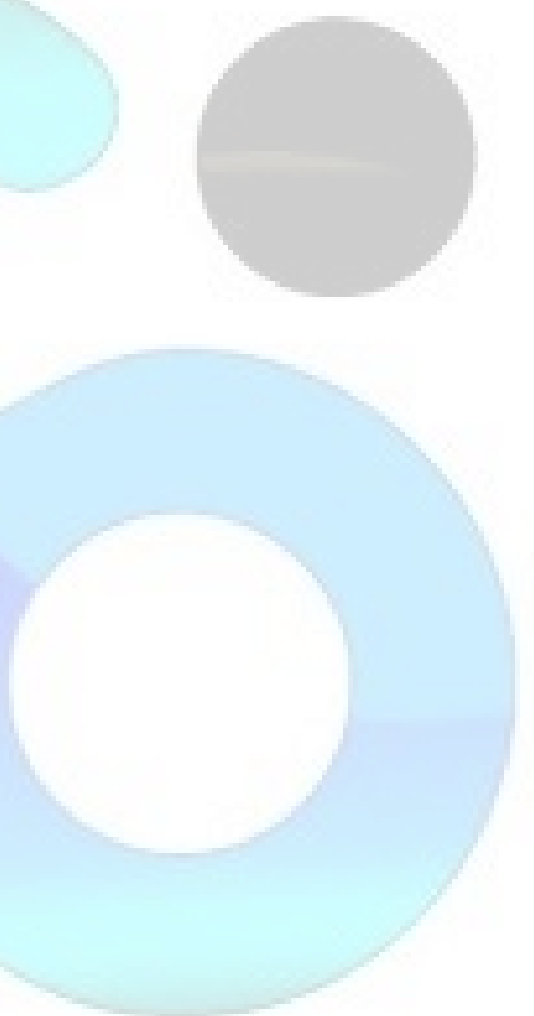